\title{
PENDAMPINGAN KETERAMPILAN CARA MENDAPATKAN, MENGGUNAKAN, MENYIMPAN, DAN MEMBUANG OBAT (DAGUSIBU) PADA MASYARAKAT
}

\section{ASSINTANCE OF SKILL IN HOW TO GET, USE, STORE AND DISPOSE OF MEDICINES (DAGUSIBU) IN THE COMMUNITY}

\author{
Sadakata Sinulingga $^{1)^{*}}$, Safyudin $^{2)}$, Fatmawati $^{3)}$, Subandrate $^{4)}$, Kusumo Hariyadi ${ }^{5)}$, \\ Rini Yana ${ }^{6)}$ \\ ${ }^{1)}$ Fakultas Kedokteran, Universitas Sriwijaya, sadakata@ fk.unsri.ac.id \\ ${ }^{2)}$ Fakultas Kedokteran, Universitas Sriwijaya, safyudinbarrie@yahoo.co.id \\ ${ }^{3)}$ Fakultas Kedokteran, Universitas Sriwijaya, karim.fatmawati@yahoo.co.id \\ ${ }^{4)}$ Fakultas Kedokteran, Universitas Sriwijaya, subandrate@ unsri.ac.id \\ ${ }^{5)}$ Fakultas Kedokteran, Universitas Sriwijaya, kusumo_hariadi@yahoo.com \\ ${ }^{6)}$ Fakultas Kedokteran, Universitas Sriwijaya, rini.yana_rh@gmail.com
}

\begin{abstract}
ABSTRAK
Saat ini, akses masyarakat terhadap obat-obatan semakin mudah. Namun, hal tersebut tidak disertai dengan pemahaman yang benar terhadap obat-obatan. Akibatnya, hal tersebut menimbulkan berbagai masalah terkait obat seperti penggunasalahan dan pembuangan obat secara sembarangan. Oleh karena itu, masyarakat perlu diberi pengetahuan dan keterampilan yang benar tentang cara mendapatkan, menggunakan, menyimpan dan membuang obat (DAGUSIBU). Kegiatan pengabdian masyarakat ini berupa pendampingan dengan kegiatan utama penyuluhan dan demonstrasi tentang DAGUSIBU terhadap masyarakat di Kelurahan Keputeraan, Kota Lubuklinggau, Sumatera Selatan. Kegiatan diikuti oleh 34 orang peserta yang terdiri dari masyarakat dan kader kesehatan. Analisis keberhasilan kegiatan dilakukan dengan melakukan evaluasi sebelum dan sesudah penyuluhan. Dari kegiatan tersebut dapat diketahui bahwa hampir seluruh peserta tidak mengetahui tentang DAGUSIBU. Setelah diberikan penyuluhan dan demonstrasi, sebagian beserta dapat memamahi dengan baik dan memiliki keterampilan sederhana dalam DAGUSIBU. Dari hasil tersebut, diharapkan masyarakat dapat menerapkannya dalam kehidupan sehari-hari.Kegiatan pengabdian masyarakat berupa penyuluhan ini telah dapat meningkatkan pengetahuan dan keterampilan masyarakat dalam DAGUSIBU sehingga perlu diupayakan kegiatan yang berkesinambungan guna mencegah penggunasalahan obat dalam masyarakat.
\end{abstract}

Kata kunci: DAGUSIBU, Obat, Pendampingan, Penyuluhan

\section{ABSTRACT}

Today, people's access to medicines is getting easier. However, this is not accompanied by a correct understanding of medicines. As a result, it raises various drug-related problems such as medicines abuse and indiscriminate disposal. Therefore, people need to be given the right knowledge and skills on how to get, use, store and dispose of medicines (DAGUSIBU). This community service activity is in the form of assistance with the main activities of counseling and demonstration about DAGUSIBU to the community in Keputeraan Village, Lubuklinggau City, South Sumatra. About 34 participants consisting of community members and health cadres attended the activity. Analysis of the success of activities carried out by evaluating before and after counseling. From these activities, it can be seen that almost no participants knew about DAGUSIBU. After being given counseling and demonstration, some of them along with be able to understand well and have simple skills in DAGUSIBU. From these results, it is expected that the community can apply it in everyday life. Community service activities in the form of counseling have been able to improve the knowledge and skills of the community in DAGUSIBU so that it needs to be pursued in a sustainable activity to prevent the use of drug problems in the community.

Keywords: Assistance, Counseling, DAGUSIBU, Medicines 
PENDAHULUAN

Obat-obatan adalah salah satu bahan yang hampir mutlak diperlukan oleh masyarakat saat ini untuk mengatasi berbagai macam gangguan kesehatan. Penggunaan obat-obatan sebagai upaya masyarakat meringankan gejala atau mempercepat proses penyembuhan penyakit. Saat ini, masyarakat mudah mendapatkan obat-obatan karena ketersediaannya yang cukup dan daya beli masyarakat yang baik. Hal tersebut berdampak tingginya peningkatan penggunaan obat-obatan oleh masyarakat [1]; [2].

Penggunaan obat-obatan yang tinggi bukanlah suatu masalah kesehatan bila sesuai dengan indikasi dan dosis. Namun, kenyataan di lapangan mengatakan bahwa tidak semua masyarakat dapat memahami perlakuan terhadap obat dengan baik. Penggunasalahan obat, penyimpanan yang salah sampai pembuangan obat secara sembarangan sudah menjadi permasalahan kesehatan yang penting saat ini. Hal tersebut disebabkan belum sampainya informasi yang benar kepada masyarakat tentang cara mendapatkan, menggunakan, menyimpan dan membuang obat (DAGUSIBU) [3].

DAGUSIBU (DApatkan, GUnakan, SImpan, BUang) adalah program yang dibuat oleh Ikatan Apoteker Indonesia (IAI) dalam rangka mewujudkan Gerakan Keluarga Sadar Obat (GKSO). DAGUSIBU berupa kegiatan pemberian pemahaman dan keterampilan kepada masyarakat agar dapat mempelakukan obat dengan baik mulai dari cara mendapatkan sampai dengan cara membuang. Kegiatan ini telah banyak dilakukan oleh IAI bekerja sama dengan berbagai instansi atau masyarakat dan diharapkan terus dilakukan guna mempercepat terwujudnya GKSO [4]; [5].

Berdasarkan informasi yang diperoleh, masyarakat Kelurahan Keputeraan, Kota Lubuklinggau, Sumatera Selatan, belum pernah mendengar tentang DAGUSIBU. Mereka belum mengetahui pentingnya DAGUSIBU bagi kesembuhan penyakit, keamanan dan keselamatan mereka. Bahkan, di antara mereka masih banyak yang mebuang obat secara sembarangan atau memberi sisa obat mereka kepada orang lain.

Melihat kondisi bahwa tingginya penggunaan obat-obat dan belum pahamnya masyarakat tentang DAGUSIBU, maka perlu dilakukan kegiatan pengabdian masyarakat berupa Pendampingan Cara Mendapatkan, Menggunakan, Menyimpan, dan Membuang Obat (DAGUSIBU) pada Masyarakat di Kelurahan Keputeraan, Kota Lubuklinggau, Sumatera Selatan.

\section{METODE PELAKSANAAN KEGIATAN}

Kegiatan pengabdian masyarakat dilakukan di Keluarahan Keputeraan, Kecamatan Lubuklinggau Barat II, Kota Lubuklinggau, Provinsi Sumatera Selatan. Kegiatan ini dilakukan pada tanggal 25-27 Oktober 2019 dengan menghadirkan 34 orang perserta yang terdiri dari masyarakat umum dan kader kesehatan.

Metode kegiatan yang dilaksanakan berupa: 
a. Penyuluhan, yakni dilakukan dengan ceramah dan diskusi dengan masyarakat tentang cara yang benar mendapatkan, menggunakan, menyimpan, dan membuang obat (DAGUSIBU). Ceramah disampaikan oleh seorang dosen yang seorang apoteker yang terlibat langsung dalam kepengurusan IAI. Alat bantu yang digunakan dalam penyuluhan berupa media informasi yang ditayangkan menggunakan laptop dan proyektor

b. Demonstrasi, yaitu memberikan pelatihan dengan melibatkan secara langsung kader kesehatan dan mahasiswa tentang DAGUSIBU. Alat bantu yang digunakan berupa leaflet atau brosus DAGUSIBU yang diambil dari IAI.

c. Evaluasi, yakni pemantauan untuk mengetahui keberhasilan kegiatan yang telah dilaksanakan. Pemantauan dilakukan di awal dan di akhir kegiatan oleh dosen dan mahasiswa dalam bentuk pertanyaan acak kepada para peserta pengabdian masyarakat.

\section{HASIL DAN PEMBAHASAN}

Kegiatan pengabdian masyarakat dilaksanakan di Kelurahan Keputeraan Kota Lubuklinggau. Kota Lubuklinggau merupakan kota terbesar kedua di Sumatera Selatan. Kota ini terletak di sebelah hulu sunggai Musi dengan keadaan geografis masuk dalam kawasan bukit barisan. Pendapatan utama kota ini adalah dari sektor pariwisata atau penerimaan jasa. Karena berupa kota transit, mobilitas penduduk kota ini terbilang cukup tinggi.

Kegiatan pengabdian masyarakat diikuti oleh 34 orang peserta yang meliputi masyarakat umum dan kader kesehatan. Kebanyakan peserta adalah perempuan (26 orang). Sebagian besar peserta berumur dalam rentang 25-45 tahun (23 orang), sebagian lagi berumur di bawah 25 tahun (8 orang) dan di atas 45 tahun (3 orang). Sebagian besar peserta berpendidikan menengah, sebagian kecil lainnya pendidikan dasar dan tidak sekolah.

Kegiatan pengabdian masyarakat juga dibantu oleh dua orang penggerak kader kesehatan setempat yakni seorang dokter umum dan seorang asisten apoteker. Sebelum dilakukan penyuluhan dilakukan pemantauan pengetahuan dasar masyarakat tentang DAGUSIBU menggunak pertanyaan acak kepada peserta. Pertanyaan yang diajukan adalah "Darimana mendapatkan obat? Bagaimana cara menggunakan obat? Dimana menyimpan obat? dan Bagaimana cara membuang obat?"

Pertanyaan acak tersebut dipandu oleh dosen dan mahasiswa kepada peserta secara langsung. Rata-rata peserta dapat memberikan jawaban yang dikategorikan cukup baik pada pertanyaan pertama dan kedua. Namun, masih banyak peserta yang memberikan jawaban terhadap pertanyaan pertama berupa "obat didapat dari dari sisa teman atau tetangga yang sakit dan obat dibeli secara bebas pada toko tidak berizin". Untuk pertanyaan ketiga dan keempat, 
sebagain besar peserta tidak dapat menjawab denga baik, karena mereka menyimpan obat di kulkas dan membuang obat sisa secara utuh dengan kemasannya.

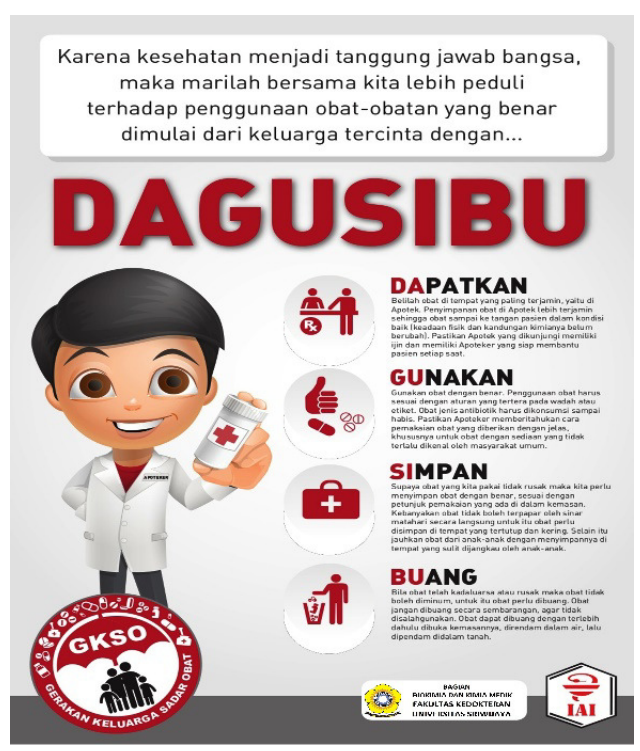

Gambar 1. Leaflet Dagusibu yang Digunakan [4]

Penyuluhan DAGUSIBU diberikan oleh seorang dosen, yang juga apoteker yang merupakan penggurus aktif IAI di Sumatera Selatan. Ceramah penyuluhan diberikan selama 25 menit lalu dilanjutkan dengan diskusi sekitar 15 menit. Dalam ceramah tersebut, dipaparkan tentang cara yang benar mendapatkan obat (sesuai dengan peraturan perundang-undangan), cara menggunakan obat (sesuai dengan intruksi yang tertulis di etiket obat), cara menyimpan obat (dalam suhu kamar) dan cara membuang obat (obat dihancurkan, dilarutkan dan dikubur). Antusias peserat sangat tinggi dilihat dari banyaknya pertanyaan yang disampaikan kepada pembicara.Penyuluhan dengan media yang tepat dapat digunakan untuk meningkatkan pengetahuan masyarakat [6].
Cara yang benar mendapatkan (DA) obat adalah dari rumah sakit, klinik, apotek, atau dari toko obat berizin. Cara tersebut sesuai dengan Peraturan Pemerintah Nomor 51 Tahun 2009 tentang pekerjaan kefarmasian. Obat-obatan didapatkan dari apotek dengan resep dokter dan hanya obat bebas dan obat bebas terbatas yang dapat dibeli di toko obat berizin atau apotek [7].

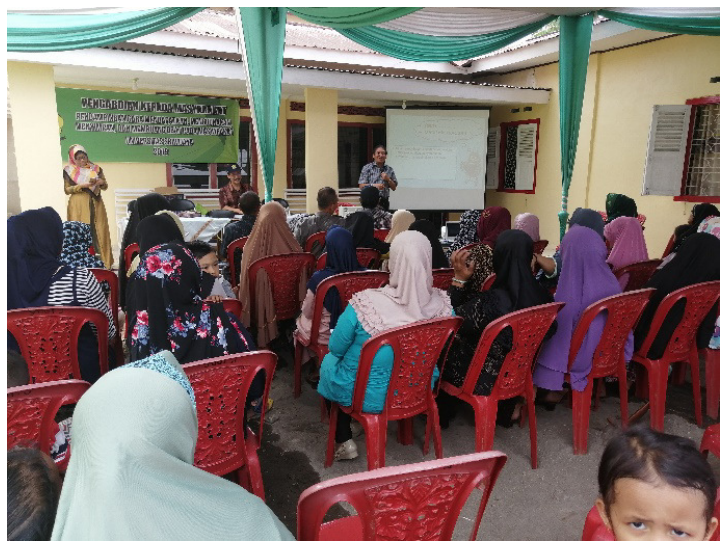

(a)

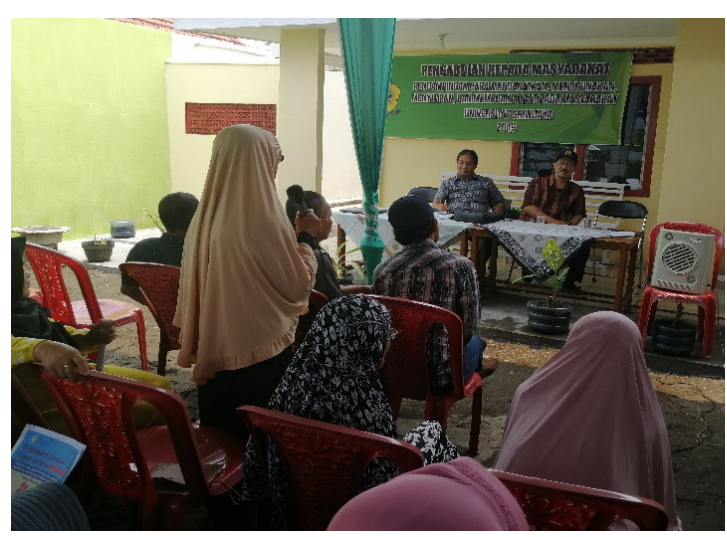

(b)

Gambar 2. Suasana Pengabdian Masyarakat (a) Penyuluhan (b) Diskusi dan Pemantauan

Cara yang benar menggunakan (GU) obat adalah dengan mengikuti instruksi yang ada di etiket obat atau dalam brosur penggunaan obat. Contoh, obat diminum dua kali sehari (pukul 07.00 dan pukul 19.00) sesudah makan. Obat-obat tertentu ada yang 
dikemas dalam bentuk kapsul, maka harus dimakan dalam bentuk kapsul dan tidak boleh dimakan dengan melepas kapsulnya. Selain itu, obat-obatan sudah ditandai obat luar, supositoria atau obat tetes [8]; [7].

Cara yang benar menyimpan (SI) obat adalah dengan mengikuti petunjuk penyimpanan yang ada dalam brosur obat. Sebagian besar obat dapat disimpan di dalam suhu ruang, seperti obat tablet dan kapsul. Sebagian lagi harus disimpan dalam kulkas seperti supositoria atau obat yang berikan melalui anus [8]; [7].

Cara yang benar membuang (BU) obat adalah dengan membuka seluruh kemasannya. Kemasannya lalu dirusak dan dibuang. Obat-obatan padat sebaiknya dihancurkan dan ditimbun dalam tanah. Obat-obatan cair sebaiknya dilarutkan atau diencerkan dengan air lalu dapat dibuang dengan sampah rumah tangga lainnya. Pembuangan obat dengan baik akan mencegah pengunaaan kembali obat-obat yang kadaluwarsa oleh orang-orang yang tidak bertangggung jawab [7].

Setelah penyuluhan, dilakukan demonstrasi untuk menguatkan pemahaman dan keterampilan peserta tentang DAGUSIBU. Demonstrasi dibantu oleh mahasiswa dan penggerak kader kesehatan dengan menggunak leaflet atau brosur yang telah disusun oleh IAI.

Kegiatan pengabdian masyarakat dilanjutkan dengan melakukan pemantauan pengetahuan dan keterampilan peserta tentang DAGUSIBU. Peserta diberikan pertanyaan acak yang sama seperti sebelum penyuluhan. Hampir seluruh peserta dapat memberikan jawaban benar. Tidak ada lagi peserta yang menjawab "memperoleh obat dari sisa obat tetangga" atau "membuang obat beserta kemasannya ke dalam kotak sampah". Melihat jawaban para peserta,maka dapat dikatakan bahwa pengabdian masyarakat ini telah memberikan output yang baik karena dapat meningkatkan pengetahuan dan keterampilan masyarakat tentang DAGUSIBU. Outcome yang diharapkan adalah para peserta mampu dan konsisten menerapkan pengetahuan dan keterampilannya tentag DAGUSIBU dalam kehidupan sehari-hari. Kegiatan pengabdian masyarakat diakhir dengan pemberian souvenir kepada peserta yang memberikan jawaban terbaik.

\section{KESIMPULAN}

Kegiatan pengabdian masyarakat berupa pendampingan cara mendapatkan, menggunakan, menyimpan, dan membuang obat (DAGUSIBU) pada Masyarakat di Kelurahan Keputeraan, Kota Lubuklinggau, Sumatera Selatan telah dapat dilaksanakan dengan baik dan telah meningkatkan pengetahuan dan keterampilan sederhana peserta tentang DAGUSIBU. Kegiatan penyuluhan DAGUSIBU dapat terus dilakukan pada masyarakat untuk mendukung terwujudnya masyarakat sehat dan GKSO sesuai dengan program yang dicanangkan IAI dan pemerintah. 


\section{UCAPAN TERIMA KASIH}

Terima kasih kepada Rektor Universitas Sriwijaya, Dekan Fakultas Kedokteran Universitas Sriwijaya, Bapak H. Surya Darma, SE, M.Si (Kepala Dinas Perindustrian dan Perdagangan Kota Lubuklinggau), dr. Anggun Permata Sari, M. Fitra Ramadhon dan M. Dias Athallah Monanda (Mahasiswa Program Studi Pendidikan Dokter FK Unsri yang telah memfasilitasi dan/atau membantu terlaksananya kegiatan pengabdian masyarakat ini.

\section{DAFTAR PUSTAKA}

[1] Balitbangkes. 2013. Pokok-Pokok Hasil Riset Kesehatan Dasar. Jakarta: Kementerian Kesehatan RI.

[2] Lestary H., A.L. Susyanty, A. Hermawan, Y. Yuniar, I.D. Sari, Rosita, Sugiharti, Khadijah. 2013. Pokokpokok Hasil Riset Kesehatan Dasar Provinsi Jawa Barat Tahun 2013. Jakarta: Kementrian Kesehatan RI.

[3] Gusnellyanti, E. 2015. Pentingnya informasi obat bagi masyarakat. Buletin Infarkes- Direktorat Jenderal Bina Kefarmasian dan Alat Kesehatan Kemenkes RI, Edisi 3: 6- 8.

[4] Pengurus Pusat IAI. 2014. Pedoman
Pelaksanaan Gerakan Keluarga Sadar Obat, Pengurus Pusat Ikatan Apoteker Indonesia. Diakses tanggal 29 Juli 2019. Diunduh dari http://iaisumbar.net/site/wpcontent/uploa ds/2014/09/GKSO-Pedoman-

Pelaksanaan.pdf.

[5] Lutfiyati, H., Yuliatuti, F., Dianita, P.S. 2017. Pemberdayaan Kader PKK dalam Penerapan DAGUSIBU (Dapatkan, Gunakan, Simpan, dan Buang) Obat dengan Baik dan Benar. The 6th University Research Colloquium. Universitas Muhammadiyah Magelang. Diakses tanggal 30 Oktober 2019.

Diunduh dari http://journal.ummgl.ac.id/index.php/ure col/article/view/1562/672.

[6] Permatasari. 2017. Efektivitas Penggunaan Media Sosial Berupa Facebook dan Instagram untuk meningkatkan Pengetahuan Mahasiswa Non Kesehatan tentang Dagusibu di Universitas Muhammadiyah Purwokerto.Diakses tanggal 25 Oktober $2019 . \quad$ Diunduh dari http://repository.ump.ac.id/4163/2/Rita\% 20Permatasari_BAB\%20I.pdf.

[7] Pemerintah Republik Indonesia. 2009. Peraturan Pemerintah Nomor 51 Tahun 2009 tentangPekerjaan Kefarmasian.Jakarta: Pemerintah RI.

[8] Chaerunissa, A.Y., Surahman, E., Imron, S.S. 2011. Farmasetika Dasar Konsep Teoritis dan Aplikasi Pembuatan Obat. Bandung: Widya Padjadjaran 